\title{
ANALISIS SIMULASI DAMPAK KEBIJAKAN BIAYA INSEMINATOR TERHADAP PETERNAK SAPI DI KECAMATAN TOMPASO KABUPATEN MINAHASA
}

\author{
Erwin Wantasen*)
}

\author{
Fakultas Peternakan Universitas Sam Ratulangi Manado-95115
}

\begin{abstract}
ABSTRAK
Tujuan dari penelitian ini adalah menganalisis keterkaitan faktor-faktor yang mempengaruhi pendapatan peternak dari usaha ternak sapi dan usahatani tanaman pangan pada kondisi penggunaan teknologi insemianasi buatan dan menganalisis pengaruh perubahan faktor eksternal terhadap pendapatan usaha ternak sapi, biaya produksi ternak sapi, biaya produksi tanaman pangan pendapatan usahatani tanaman pangan, biaya kesehatan ternak dan biaya kandang pada kondisi penggunaan teknologi inseminasi buatan. Pengukuran teknologi inseminasi buatan menggunakan pendekatan biaya inseminator . Penelitian ini adalah studi kasus terhadap 70 peternak sapi di desa Tonsewer Kecamatan Tompaso Kabupaten Minahasa yang dipilih secara acak. Model persamaan simultan dengan metode 2SLS digunakan untuk mengestimasi semua parameter penelitian. Hasil penelitian menunjukkan bahwa model ekonomi peternak yang dibangun dapat menjelaskan dengan baik keterkaitan dengan pendapatan dan biaya produksi pada usahaternak sapi maupun usahatani tanaman pangan . Hasil analisis simulasi menunjukkan bahwa dampak peningkatan biaya inseminator sebesar $15 \%$ adalah alternatif terbaik karena dapat meningkatkan pendapatan usaha ternak sapi $9,37 \%$ dan biaya total produksi ternak sapi relative kecil sebesar $0,24 \%$, biaya uasahatani tanaman pangan meningkat $3,62 \%$, pendapatan usahatani tanaman pangan meningkat $5,86 \%$, biaya obat-obatan sapi meningkat $2,52 \%$ dan biaya kandang meningkat $2,78 \%$. Hasil penelitian menunjukkan bahwa kebijakan biaya inseminasi mampu meningkatkan penampilan
\end{abstract}

*Jurusan Sosial Ekonomi Peternakan ekonomi rumah tangga peternak sapi di wilayah penelitian

Kata kunci : Teknologi inseminasi buatan , Biaya inseminator, pendapatan peternak sapi, model ekonomi peternak sapi

\section{ABSTRACT}

THE SIMULATION ANALYSIS OF INSEMINATOR COST POLICY IMPACT TO CATTLE FARMERS ON TOMPASO SUBDISTRICT MINAHASA REGENCY. The objectives of this study were to analyze factors affecting the farmers' income from the cattle business and farming crops under condition of the usage of artificial insemination technology and to analyze the effects of the external factor changing toward the income of beef cattle business, the costs of cattle production, the cost of food crop production, food crops farm income, animal health costs and the cost of the barn with the condition of the artificial technology usage. The measurement of artificial insemination used the inseminator cost approach. This research was a case study of 70 cattlemen in the village of Tonsewer Tompaso Sub district Minahasa Regency selected by random sampling. Model of simultaneous equations with the method of 2 SLS was used to estimate all the parameters of the study. The result of research showed that the economic model of cattlemen could explain the relation of inseminator cost with income and costs of production in cattle and food crops well. The simulation analysis indicated that effect of inseminator cost policy on household's economy was that $15 \%$ increasing of inseminator cost was the best alternative scenario that can increases income of cattle business $9,37 \%$, beef production cost $0.24 \%$, food crops production cost $3,62 \%$, income of food crops business $5.86 \%$, cattle medication cost 2,52\% and barn cost $2.78 \%$. These 
results indicated that the inseminator cost policy could improve economics performance of cattle farmers.

\section{Keywords: Simulation analysis, Inseminator cost, Income of cattle farmers, food crops, economic model of cattlemen}

\section{PENDAHULUAN}

Ternak sapi merupakan salah satu ternak yang memiliki potensi untuk dikembangkan di Kabupaten Minahasa. Usaha ternak sapi merupakan sumber pendapatan bagi rumah tangga dipedesaan, dapat menyerap tenaga kerja, sumber tenaga kerja mengolah lahan usahatani dan pengangkutan. Jumlah populasi ternak sapi di Sulawesi Utara hingga tahun 2009 adalah 108.335 ekor dan terbanyak terdapat di wilayah Kabupaten Minahasa sebanyak 27.938 ekor (Sulawesi Utara Dalam Angka, 2010). Proses produksi, pendapatan dan alokasi tenaga kerja dalam rumahtangga peternak sapi merupakan satu unit kesatuan yang saling terkait, sehingga setiap terjadi perubahan dalam kebijakan yang mengatur aktivitas usaha ternak sapi akan berpengaruh terhadap produksi, pendapatan, dan penggunaan tenaga kerja (Rochaeni dan Lokollo 2005; Hartono, 2006). Peternak sapi di Desa Kanonang III selain beternak juga mengusahakan tanaman pangan seperti padi, jagung, kacang tanah, kacang merah , tomat dan bawang merah untuk memenuhi kebutuhan rumahtangga. Usahatani ternak sapi dan tanaman pangan merupakan usaha yang dilakukan secara turun temurun, dan saling berkaitan satu dengan lainnya. Ternak sapi digunakan sebagai tenaga kerja pengolah lahan pertanian dan mengangkut hasil usahatani tanaman pangan, selanjutnya kotoran sapi menjadi sumber pupuk untuk menyuburkan lahan pertanian yang hasilnya dapat dimanfaatkan sebagai pakan ternak (Hoddi, 2011)

Usaha ternak sapi di Kecamatan Tompaso Kabupaten Minahasa sebagian besar adalah usaha peternakan rakyat yang sampai saat ini dikelola secara tradisional dengan skala usaha kecil, dan menggunakan teknologi tradisional. Karakter utama rumah tangga petani peternak menunjukkan bahwa usaha ternak dikelola oleh rumahtangga dan anggota keluarganya secara turun-temurun. Tenak sapi dipelihara untuk membantu peternak mengolah lahan usahatani dan pengangkutan hasil pertanian. Fenomena ini merupakan perilaku rumah tangga sebagai produsen dalam aktivitas ekonomi. Rumah tangga selain berperan sebagai produsen, penyedia tenaga kerja, juga sebagai konsumen. Tenaga kerja anggota keluarga dialokasikan baik untuk bekerja pada usaha ternak dan usaha tani lainnya seperti tanaman pangan untuk menghasilkan pendapatan. 
Diwyanto (2008) berpendapat program IB pada sapi bertujuan untuk memperbaiki mutu ternak melalui cara kawin buatan yang pada akhirnya berupaya secara kualitatif dapat meningkatkan produksi dan pendapatan peternak. Meskipun demikian masih terdapat masalah yang dihadapi oleh peternak di daerah penelitian dalam hubungannya dengan penggunaan teknologi inseminasi yaitu ketersediaan bibit sapi peranakan ongole (PO) untuk inseminasi buatan (IB) dan tenaga inseminator yang tidak kontinyu. Kondisi tersebut menyebabkan nilai Service Per Conception (S/C) dari program inseminasi di Kabupaten Minahasa lebih dari satu sehingga jarak beranak menjadi lebih panjang. Untuk mengatasi masalah tersebut biasanya peternak akan mengawinkan sapi betinanya secara alami padahal biaya kawin alam relatif lebih mahal dibandingkan dengan inseminasi yang masih disubsidi oleh pemerintah ditambah lagi dengan ketersediaan pejantan unggul yang seringkali hanya dapat diperoleh di desa-desa tetangga dari peternak. Kondisi tersebut sesuai dengan pendapat Hadi dan Ilham ( 2002) mengatakan bahwa upaya IB masih terkendala kekurangan tenaga inseminator , semen atau bibit sapi unggul, dan fasilitas IB.
Winarso, dkk (2005) mengatakan bahwa pada usahatani skala kecil pendapatan merupakan penerimaan bersih (net return) dan pendapatan ini merupakan selisih antara seluruh penerimaan dengan biaya yang dikeluarkan petani. Dengan demikian pendapatan petani terdiri atas hasil penjualan produksi, upah tenaga kerja keluarga dan bunga modal sendiri (alat, lahan dan lainnya). Pendapatan dapat dibagi menjadi tiga yaitu 1). Gross Income (pendapatan kotor) adalah pendapatan usahatani yang belum dikurangi dengan biaya. Gross income terdiri atas bentuk cash dan non cash. Bentuk cash merupakan hasil rill yang diterima sedangkan bentuk non cash adalah produk yang tidak dijual tetapi untuk dikonsumsi atau ditimbun, 2) Net income adalah gross income dikurangi dengan biaya atau pendapatan setelah dikurangi biaya, 3) Pendapatan pengelola adalah hasil pengurangan dari total output dengan total input, baik input yang benarbenar dibayar maupun yang hanya diperhitungkan . Apabila diterapkan pada petani kecil pada umumnya negatif. Nilai masukan atau biaya produksi usaha ternak sapi menurut teori ekonomi adalah semua beban yang harus ditanggung oleh produsen (petani) untuk menyediakan barang agar siap dipakai konsumen dan dalam perhitungan pendapatan dapat dikelompokkan menjadi dua yaitu nilai 
masukan atau biaya tetap dan tidak tetap ( Sudarsono, 1995). Dalam jangka pendek terdapat biaya tetap dan tidak tetap, tetapi dalam jangka panjang semua biaya adalah biaya variabel.. Biaya tetap merupakan biaya yang tidak terkait dengan volume produksi, artinya dalam periode tertentu jumlahnya tidak berubah misalnya penyusutan kandang, alat bangunan, bunga atas modal dan lain-lain. Sedangkan biaya tidak tetap adalah biaya yang terkait langsung dengan volume produksi artinya perubahan biaya variabel akan menyebabkan perubahan volume produksi yang dihasilkan misalnya biaya makanan ternak , obat-obatan dan vaksin, biaya kandang, biaya inseminator.

Untuk meningkatkan pendapatan usaha tani ternak sapi maka peternak memanfaatkan teknologi inseminasi buatan (IB) ataupun sistim kawin alami yang pelaksanaannya membutuhkan biaya yaitu biaya inseminator untuk IB dan biaya kawin alami dengan menyewa sapi pejantan. Agar ternak tumbuh optimal maka peternak juga mengeluarkan biaya untuk makanan ternak, biaya kesehatan ternak, biaya kandang dan biaya ternaga kerja. Pendapatan peternak sapi juga berasal dari usahatani tanaman pangan seperti padi , jagung, kacang tanah, kacang merah, tomat dan bawang merah. Proses produksi untuk menghasilkan pendapatan dalam usahatani tanaman pangan membutuhkan biaya produksi seperti biaya pupuk, biaya obat-obatan dan biaya tenaga kerja. Karena itu peternak sapi akan mengalokasikan pendapatannya untuk usaha ternak sapi dan tanaman pangan.

Penelitiann mengenai pemanfaatan teknologi pada usaha ternak sapi masih terbatas pada teknologi integrasi tanaman dan ternak sapi dan dampaknya terhadap produksi dan pendapatan peternak (Fakoya 2007; Elly, dkk 2009; Priyanti, 2009), dampak teknologi penggemukan sapi dan teknologi makanan ternak terhadap pendapatan usahaternak sapi (Karyasa, 2007) Penelitian tentang biaya inseminator masih terbatas pada dampaknya terhadap pendapatan usahaternak sapi ( Sulin , et.al. 2006; Eniza dkk, 2006)), sedangkan informasi berkaitan dengan dampak biaya inseminator terhadap pendapatan usaha ternak sapi, biaya produksi usahaternak sapi dan pendapatan dari usahatani tanaman pangan masih sangat terbatas. Pengembangan populasi ternak sapi dari hasil inseminasi di wilayah penelitian masih menghadapi kendala berupa keterbatasan jumlah inseminator yang harus melayani kebutuhan seluruh peternak di wilayah Kecamatan Tompaso, sehingga peternak mengeluarkan biaya tambahan untuk membayar petugas inseminasi (biaya inseminator) pada setiap kali inseminasi dilakukan. Petugas 
inseminasi sangat senang bila diberi ongkos tambahan saaat mereka melakukan proses inseminasi sehingga diharapkan dapat memotivasi mereka untuk melaksanakan tugasnya dan diharapkan dapat memperbaiki nilai service per conception dan calving interval (jarak beranak) ternak sapi betina. Fenomena ini menimbulkan pertanyaan sejauh mana dampak dari biaya inseminator terhadap pendapatan dan biaya produksi usaha ternak sapi dan sejauh mana pendapatan ternak sapi mempengaruhi biaya kandang, biaya kesehatan ternak sapi dan pendapatan usaha tani tanaman pangan yang dikelola petani.

Berdasarkan pemikiran di atas penelitian ini bertujuan (1) Menganalisis keterkaitan biaya inseminator terhadap pendapatan peternak dari usaha ternak sapi dan usahatani tanaman pangan

Menganalisis pengaruh perubahan faktor eksternal terhadap pendapatan usaha ternak sapi, biaya produksi ternak sapi, biaya produksi tanaman pangan pendapatan usahatani tanaman pangan, biaya kesehatan ternak dan biaya kandang pada kondisi penggunaan inseminasi.

\section{MATERI DAN METODE PENELITIAN}

\section{Populasi dan Sampel Penelitian}

Penelitian merupakan studi kasus yang dilakukan di Desa Tonsewer
Kecamatan Tompaso Kabupaten Minahasa Propinsi Sulawesi Utara pada bulan Oktober 2012 hingga Desember 2012. Desa Tonsewer dipilih menjadi lokasi penelitian karena memiliki populasi ternak sapi terbanyak di Kecamatan Tompaso yaitu 583 ekor pada tahun 2011 (Sulawesi Utara Dalam Angka, 2012). Pemilihan sampel dengan menggunakan metode simple random sampling terhadap 70 peternak sapi yang sudah menggunakan teknologi inseminasi buatan pada ternak sapinya . Data penelitian adalah data primer yaitu biaya inseminator, biaya kawin alami, pendapatan usaha sapi, biaya kesehatan ternak, pendapatan usahatani tanaman pangan, biaya produksi ternak sapi, biaya produksi tanaman pangan yang dikumpulkan melalui wawancara dengan menggunakan daftar pertanyaan.

\section{Metode Analisis Data}

Untuk menjawab tujuan penelitian maka digunakan pendekatan model ekonometrika (Greene 2003). Pengukuran teknologi inseminasi buatan menggunakan pendekatan biaya inseminator. Model ekonomi peternak sapi yang dibangun menggunakan persamaan simultan sehingga dapat menjelaskan keterkaitan faktor-faktor yang mempengaruhi pendapatan usahaternak sapi dan usahatani tanaman pangan pada kondisi penggunaan teknologi inseminasi. Model memiliki 6 persamaan terdiri dari 5 persamaan 
struktural dan 1 persamaan identitas. Jumlah peubah endogen sebanyak 6 dan peubah eksogen sebanyak 4. Identifikasi model dilakukan untuk menentukan metode pendugaan parameter. Menurut Koutsoiyannis (1977) bahwa persamaan yang teridentifikasi dapat diketahui dengan membandingkan exclude variabel (K-M) dengan jumlah persamaan dikurangi satu (G-1). Karena model persamaan simultan terdiri atas 6 persamaan $(\mathrm{G})$ dan 10 variabel $(\mathrm{K})$ dan jumlah predetermined variabel dalam setiap persamaan maksimum 3 (M) maka persamaan yang dibangun termasuk overidentified (K-M > G-1) sehingga untuk menduga parameter estimasi digunakan metode 2 SLS ( Two Stage Least Square). Untuk mengetahui pengaruh perubahan faktor eksternal terhadap pendapatan dan biaya produksi usahaternak sapi dan tanaman dilakukan analisis simulasi terhadap (1) biaya inseminator naik 15 persen, (2) biaya kawin alami naik 15 persen, (3) biaya makanan ternak naik 15 persen, (4) biaya tenaga kerja keluarga pada usaha sapi turun 15 persen, (5) biaya inseminator dan biaya kawin alami turun 15 persen, (6) kombinasi simulasi 2 dan 4 dan (7) kombinasi simulasi 3 dan 4. Simulasi dilakukan setelah terlebih dahulu model di validasi dengan menggunakan kriteria Theil's Inequality Coeficient dan dekomposisinya (Greene, 2003) untuk membandingkan nilai aktual dengan nilai dugaan peubah endogen. Dekomposisi dari $\mathrm{U}$ - Theil terdiri atas $\mathrm{U}^{\mathrm{M}}$ (bias rata-rata ) untuk mengukur seberapa jauh nilai ratarata simulasi dan aktualnya menyimpang satu dengan lainnya, $\mathrm{U}^{\mathrm{S}}$ ( bias kemiringan regresi) untuk mengukur penyimpangan kemiringan regresi dan $\mathrm{U}^{\mathrm{C}}$ (bias covariance) adalah indikator komponen bias residual. Suatu model mempunyai daya prediksi yang baik apabila nilai $\mathrm{U}^{\mathrm{M}}$ dan $\mathrm{U}^{\mathrm{S}}$ mendekati nol dan $\mathrm{U}^{\mathrm{C}}$ mendekati satu. Pengolahan data menggunakan program Statistical Analysis System (SAS) versi 9.1.3. Model persamaan simultan yang dibangun adalah :

1. Pendapatan Usaha Ternak Sapi

PDS $=\mathrm{a} 0+\mathrm{a} 1 \mathrm{BIN}+\mathrm{a} 2 \mathrm{BKA}$ $+\mathrm{a} 3 \mathrm{BPH}+\mathrm{ei}$

Tanda parameter dugaan diharapkan a0 $<0$, a1, a2, a3 $>0$

2. Biaya Produksi Ternak Sapi $\mathrm{BPTS}=\mathrm{BKD}+\mathrm{BPH}+\mathrm{BIN}$ $+\mathrm{BKA}+\mathrm{BOB}+\mathrm{BTK}$

$\mathrm{BOB}=\mathrm{c} 0+\mathrm{c} 1 \mathrm{PDS}+\mathrm{ei}$

Tanda parameter dugaan diharapkan $\mathrm{c} 0, \mathrm{c} 1>0$

$\mathrm{BKD}=\mathrm{d} 0+\mathrm{d} 1 \mathrm{PDS} \mathrm{d} 2 \mathrm{BIN}+\mathrm{ei}$

Tanda parameter dugaan diharapkan d0, d1 $>0, d 2<0$

3. Biaya Produksi Tanaman Pangan $\mathrm{BTP}=\mathrm{bo}+\mathrm{b} 1 \mathrm{BPTS}+\mathrm{b} 2 \mathrm{PTP}+\mathrm{ei}$ 
Tanda parameter dugaan diharapkan b0,b1 <0, b1 $>0$

4 Pendapatan Usahatani Tanaman Pangan

$\mathrm{PTP}=\mathrm{e} 0+\mathrm{e} 1 \mathrm{BTP}+\mathrm{e} 2 \mathrm{BTK}+$ e3PDS + ei

Tanda parameter dugaan diharapkan $\mathrm{e} 0, \mathrm{e} 1, \mathrm{e} 3>0, \mathrm{e} 2<0$

dimana, PDS adalah pendapatan dari usaha ternak sapi (Rp/tahun/peternak), BIN adalah biaya inseminator (Rp/tahun/peternak), ), BKA adalah biaya kawin alami (Rp/thn/peternak), BPH adalah biaya makanan ternak (Rp/thn/peternak), BTP adalah biaya produksi usahatani tanaman pangan (Rp/tahun/peternak), BPTS adalah biaya produksi usahatani ternak sapi (Rp/tahun/peternak), BKD adalah biaya kandang (Rp/thn/peternak), BOB adalah biaya kesehatan ternak sapi (Rp/thn/peternak), BTK adalah biaya tenaga kerja peternak pada usaha sapi (Rp/thn/peternak), PTP adalah pendapatan dari usahatani tanaman pangan (Rp/tahun/peternak)

\section{HASIL DAN PEMBAHASAN}

\section{Dampak Kebijakan Biaya Inseminator Terhadap Pendapatan Peternak Sapi}

Hasil estimasi model ekonomi peternak sapi dilihat pada Tabel 1 . Semua tanda estimasi untuk peubah yang mempengaruhi peubah endogen telah sesuai kriteria ekonomi. Sebagian besar peubah eksogen berpengaruh nyata terhadap peubah endogen pada taraf 5 persen

Hasil analisis menunjukkan bahwa pendapatan dari usaha ternak sapi dipengaruhi oleh biaya inseminator, biaya kawin alami dan biaya makanan ternak dengan probabilitas $<$,0001. Nilai koefisien determinasi $\left(\mathrm{R}^{2}\right)$ sebesar 0,7224 yang artinya biaya inseminator, biaya kawin alami dan biaya makanan ternak mempengaruhi pendapatan usaha ternak sapi sebesar 72,24 persen sedang sisanya sebesar 27,76 persen merupakan faktor lain yang tidak ada dalam model. Biaya inseminator berpengaruh positif terhadap pendapatan usaha ternak sapi dengan parameter sebesar 542,35 dan secara statistik nyata pada selang uji $<, 0001$. Biaya kawin alami berpengaruh positif terhadap pendapatan usaha ternak sapi dengan parameter 94,15 dan secara statistik sangat nyata pada selang uji < ,0001. Biaya makanan ternak berpengaruh positif terhadap pendapatan usaha ternak sapi dengan parameter 1,62 dan secara statistik sangat nyata pada selang uji 0,0395

Hasil analisis menunjukkan bahwa biaya produksi tanaman pangan dipengaruhi oleh biaya produksi ternak 
sapi dan pendapatan usahatani tanaman pangan dengan probabilitas 0,0005 . Nilai koefisien determinasi $\left(\mathrm{R}^{2}\right)$ sebesar 0,5867 yang artinya biaya produksi ternak sapi dan pendapatan usahatani tanaman pangan mempengaruhi biaya produksi tanaman pangan sebesar 58,67 persen sedang sisanya sebesar 41,33 persen merupakan faktor lain yang tidak ada dalam model. Biaya produksi ternak sapi berpengaruh negatif terhadap biaya produksi tanaman pangan dengan parameter sebesar $-0,32$ dan secara statistik tidak nyata pada selang uji 0,1344 . Pendapatan usahatani tanaman pangan berpengaruh positif terhadap biaya produksi tanaman pangan dengan parameter 1,14 dan secara statistik nyata pada selang uji 0,0003. Hasil analisis menunjukkan bahwa biaya kesehatan ternak dipengaruhi oleh pendapatan usahaternak sapi dengan probabilitas $<, 0001$. Nilai koefisen determinasi sebesar 0,7298 yang berarti nilai tambah ternak sapi mempengaruhi penerimaan penjualan ternak sapi sebesar 72,98 persen sedang sisanya sebesar 27,02 persen merupakan faktor lain yang tidak ada dalam model . Pendapatan usaha ternak sapi berpengaruh positif terhadap biaya kesehatan ternak dengan parameter sebesar 0,0012 dan secara statistik sangat nyata pada selang uji $<, 0001$
Hasil analisis menunjukkan bahwa biaya kandang dipengaruhi oleh pendapatan dari usaha ternak sapi dan biaya inseminator dengan probabilitas $<, 0001$. Nilai koefisien determinasi $\left(\mathrm{R}^{2}\right)$ sebesar 0,6267 yang artinya pendapatan usaha ternak sapi dan biaya inseminator mempengaruhi biaya kandang sebesar 62,67 persen sedang sisanya sebesar 37,33 persen merupakan faktor lain yang tidak ada dalam model. Pendapatan usaha ternak sapi berpengaruh positif terhadap biaya kandang dengan parameter sebesar 0,0060 dan secara statistik nyata pada selang uji 0,0001 . Biaya inseminator berpengaruh negatif terhadap biaya kandang dengan parameter -2,81 dan secara statistik nyata pada selang uji 0,0414. Hasil analisis menunjukkan bahwa pendapatan usahatani tanaman pangan dipengaruhi oleh biaya produksi tanaman pangan, biaya tenaga kerja keluarga pada usaha sapi dan pendapatan usaha ternak sapi dengan probabilitas $<, 0001$ Nilai koefisien determinasi $\left(\mathrm{R}^{2}\right)$ sebesar 0,5877 yang artinya biaya produksi tanaman pangan, biaya tenaga kerja keluarga pada usaha sapi dan pendapatan usaha ternak sapi mempengaruhi pendapatan usahatani tanaman pangan sebesar 58,77 persen sedang sisanya sebesar 41,23 persen merupakan faktor lain yang tidak ada dalam model. 
Biaya produksi tanaman pangan berpengaruh positif terhadap pendapatan usahatani tanaman pangan dengan parameter sebesar 0,59 dan secara statistik tidak nyata pada selang uji 0,2340. Biaya tenaga kerja keluarga pada usaha sapi berpengaruh negatif terhadap pendapatan usahatani tanaman pangan dengan parameter $-0,09$ dan secara statistik tidak nyata pada selang uji 0,3526 . Pendapatan usaha ternak sapi berpengaruh positif terhadap pendapatan usahatani tanaman pangan dengan parameter 0,08 dan secara statistik nyata pada selang uji 0,0090

\section{Validasi Model}

Hasil validasi model (Tabel 2) menunjukkan nilai $\mathrm{U}^{\mathrm{M}}$ mendekati nol berarti model yang dibangun tidak mengalami bias sistematik. Nilai $U^{S}$ mendekati nol berarti prediksi hasil analisis simulasi dapat mengikuti dengan baik fluktuasi data aktualnya. Nilai $\mathrm{U}^{\mathrm{C}}$ mendekati satu berarti kesalahan tidak berarti dan tidak mengikuti pola tertentu tetapi menyebar pada semua contoh pengamatan. Hasil analisis validasi mengindikasikan bahwa model ekonomi peternak sapi cukup valid digunakan sebagai alat simulasi

Tabel 1. Hasil Estimasi Model Ekonomi Peternak Sapi

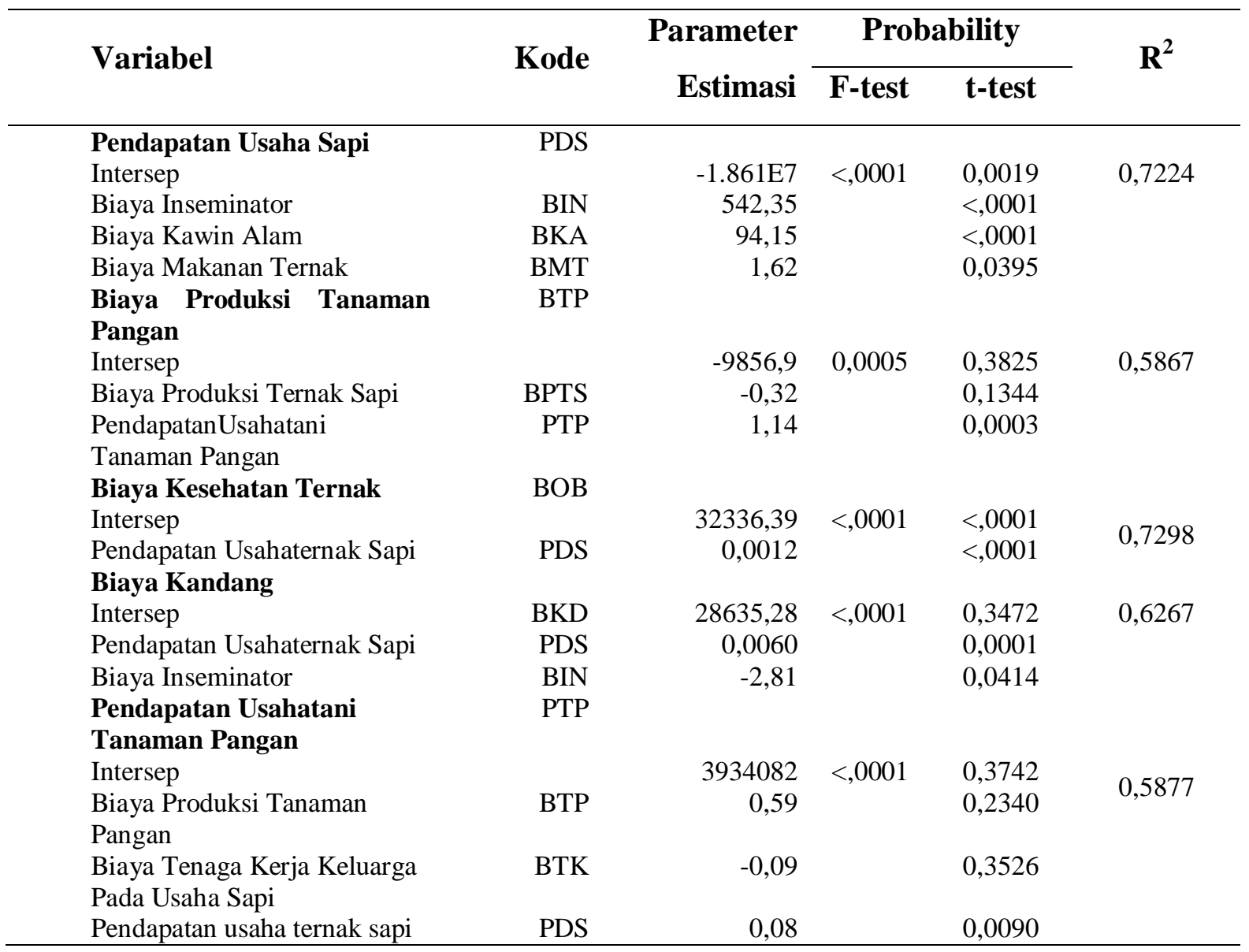

Sumber : Hasil Pengolahan Data Primer SAS 9.1 for Windows 
Tabel 2. Indikator Validasi Model

\begin{tabular}{lccc}
\hline \multicolumn{1}{c}{ Peubah Endogen } & $\mathbf{U}^{\mathbf{M}}$ & $\mathbf{U}^{\mathbf{S}}$ & $\mathbf{U}^{\mathbf{C}}$ \\
\hline Pendapatan Usaha Ternak Sapi (PDS) & 0,00 & 0,06 & 0,94 \\
Biaya Produkasi Ternak Sapi (BPTS) & 0,00 & 0,04 & 0,96 \\
Biaya Produksi Tanaman Pangan (BTP) & 0,00 & 0,11 & 0,89 \\
Pendapatan Usahatani Tanaman Pangan & 0,00 & 0,28 & 0,72 \\
(PTP) & 0,00 & 0,14 & 0,86 \\
Biaya Kesehatan Ternak (BOB) & 0,00 & 0,11 & 0,89 \\
Biaya Kandang (BKD) & & &
\end{tabular}

Sumber : Hasil Pengolahan Data Primer SAS 9.1 for Windows

Keterangan : $\mathrm{U}^{\mathrm{M}}=$ bias rata-rata

$$
\begin{aligned}
& \mathrm{U}^{\mathrm{S}}=\text { bias kemiringan regresi } \\
& \mathrm{U}^{\mathrm{C}}=\text { bias covariance }
\end{aligned}
$$

Tabel 3. Simulasi Dampak Perubahan Faktor Eksternal

\begin{tabular}{lcccccccc}
\hline \multirow{2}{*}{ Peubah } & Simulasi & \multicolumn{7}{c}{ Alternatif Skenario (\%) } \\
\cline { 3 - 9 } & Dasar & SIM 1 & SIM 2 & SIM 3 & SIM 4 & SIM 5 & SIM 6 & SIM 7 \\
\hline PDS & 39601901 & 9,37 & 5,32 & 3,10 & 0,00 & $-10,81$ & 4,12 & 4,10 \\
BPTS & 8825293 & 0,24 & 0,65 & 8,64 & $-0,92$ & $-1,23$ & $-0,59$ & 7,55 \\
BTP & 16594517 & 3,62 & 3,61 & $-2,18$ & 0,83 & $-8,13$ & 3,44 & $-1,42$ \\
PTP & 5684048 & 5,86 & 3,97 & $-0,62$ & 0,41 & $-5,49$ & 2,85 & $-0,21$ \\
BOB & 81759,6 & 2,52 & 2,88 & 1,87 & 0,00 & $-6,61$ & 5,23 & 1,28 \\
BKD & 115323 & 2,78 & 5,39 & 2,25 & 0,00 & $-10,22$ & 7,04 & 3,63 \\
\hline
\end{tabular}

Sumber : Hasil Pengolahan Data Primer SAS 9.1 for Windows

Keterangan : SIM 1= Biaya inseminator naik $15 \%$

SIM 2 = Biaya kawin alami naik $15 \%$

SIM 3 = Biaya makanan ternak naik $15 \%$

SIM 4 = Biaya tenaga kerja keluarga pada usaha sapi turun $15 \%$

SIM 5 = Biaya inseminator dan biaya kawin alam turun $15 \%$

SIM 6 = Kombinasi SIM 2 dan SIM 4

SIM 7 = Kombinasi SIM 3 dan SIM 4 


\section{Dampak Perubahan Faktor Eksternal}

Skenario perubahan faktor

eksternal akan dilihat dampaknya terhadap peubah endogen pendapatan usaha ternak sapi, biaya produksi ternak sapi, biaya produksi tanaman pangan, pendapatan usahatani tanaman pangan, biaya kesehatan ternak dan biaya kandang pada kondisi penggunaan teknologi inseminasi buatan (Tabel 3).

Hasil analisis estimasi model ekonomi peternak sapi dalam penggunaan teknologi inseminasi menunjukkan bahwa biaya inseminator berpengaruh pada pendapatan usaha ternak sapi karena peningkatan biaya inseminator akan memotivasi tenaga inseminator untuk melakukan proses inseminasi sesuai waktunya sehingga peternak memperoleh tambahan anak sapi setiap tahun dan pendapatannya bertambah. Biaya kawin alami berpengaruh terhadap pendapatan usaha ternak sapi karena meningkatnya biaya akan mendorong pemilik sapi pejantan untuk menyediakan sapi pejantan yang berkualitas sehingga akan menghasilkan anak sapi yang bernilai jual tinggi bila dikawinkan dengan sapi betina milik peternak. Biaya makanan ternak berpengaruh terhadap pendapatan usahaternak sapi karena peternak memberikan makanan yang berkualitas dari lahan pertaniannya seperti rumput gajah, jagung muda, jerami padi dan ditambah dengan makanan konsentrat sehingga akan meningkatkan bobot badan sapi dan harga jualnya. Hasil ini sesuai dengan penelitian Soedjana (2007) bahwa sistem usaha tani tanaman jagung dengan ternak sapi memberikan keuntungan lebih besar dalam suatu lahan tertentu.

Pendapatan usahatani tanaman pangan berpengaruh terhadap biaya produksi tanaman pangan karena adanya tambahan pendapatan mendorong peternak untuk menginvestasikan kembali sebagian hasilnya pada lahan usahataninya dan memperbesar luas usahatani garapan sehingga membutuhkan jumlah bibit, pupuk, tenaga kerja dan obat-obatan yang lebih banyak.

Pendapatan usaha ternak sapi berpengaruh terhadap biaya kesehatan ternak karena nilai jual ternak sapi di daerah penelitian sangat ditentukan oleh kondisi kesehatan ternak sehingga peternak bersedia mengeluarkan tambahan biaya untuk mencegah dan mengobati ternak yang sakit.

Biaya inseminator berpengaruh negatif terhadap biaya kandang karena keterbatasan anggaran yang dimiliki peternak. Meningkatnya biaya inseminator menyebabkan peternak mengurangi anggaran untuk membuat kandang. Hal ini sejalan dengan penelitian Elly, dkk (2009) bahwa karena keterbatasan budget maka meningkatnya biaya input pupuk urea akan 
mengurangi penggunaan input pupuk TSP pada usahatani jagung. Pendapatan usaha ternak sapi berpengaruh terhadap biaya kandang karena meningkatnya pendapatan menunjukkan adanya peningkatan jumlah pemilikan ternak sapi sehingga peternak akan mengeluarkan biaya tambahan untuk membuat kandang guna melindungi ternaknya.

Pendapatan usaha ternak sapi berpengaruh terhadap pendapatan usahatani tanaman pangan karena peternak menginvestasikan sebagian pendapatan yang diperoleh dari usaha ternak sapi untuk menambah frekuensi pengolahan lahan dan ekspansi lahan sehingga meningkatkan produksi dan pendapatan usahatani tanaman pangan (jagung, kacang tanah dan lainnya)

Hasil analisis dampak perubahan faktor eksternal menunjukkan bahwa penggunaan teknologi inseminasi buatan yang ditunjukkan oleh peningkatan biaya inseminator sebesar 15 persen (SIM 1) memberikan dampak paling baik terhadap semua variabel ekonomi peternak sapi dibandingkan dengan perubahan lainnya (SIM 2, SIM 3, SIM 4, SIM 5, SIM 6 dan SIM 7). Hal itu dapat dilihat dari besarnya perubahan pendapatan usaha sapi, biaya produksi sapi, biaya usahatani tanaman pangan, pendapatan usahatani tanaman pangan, biaya kesehatan ternak dan biaya kandang yang peningkatannya relatif lebih besar. Penurunan biaya inseminator dan biaya kawin alam masing-masing sebesar 15 persen (SIM 5) telah menurunkan semua variabel ekonomi peternak sapi. Meningkatnya biaya makanan ternak sebesar 15 persen (SIM 3) telah meningkatkan sebagian besar variabel ekonomi peternak kecuali pada biaya produksi dan pendapatan usahatani tanaman pangan.

\section{KESIMPULAN}

1. Keterkaitan faktor-faktor yang mempengaruhi ekonomi peternak sapi adalah biaya inseminator, biaya kawin alami, dan biaya makanan ternak mempengaruhi pendapatan usaha ternak sapi. Pendapatan usaha sapi dan biaya inseminator berpengaruh terhadap biaya kandang. Pendapatan usaha sapi , biaya produksi tanaman pangan dan biaya tenaga kerja keluarga pada usaha sapi berpengaruh terhadap pendapatan usahatani tanaman pangan. Biaya usahatani tanaman pangan dipengaruhi oleh biaya produksi ternak sapi 2 Dampak faktor eksternal terhadap ekonomi rumah tangga peternak sapi adalah, peningkatan biaya inseminator sebesar 15 persen meningkatkan pendapatan usaha sapi, biaya produksi sapi, biaya usahatani tanaman pangan, pendapatan usahatani tanaman pangan, biaya kesehatan ternak dan 
biaya kandang. Biaya inseminator meningkatkan semua variabel ekonomi peternak sapi yang diteliti

\section{SARAN}

1. Alternatif kebijakan yang direkomendasikan adalah pertama pemerintah diharapkan dapat mengintroduksi secara kontinyu bibit atau semen sapi PO melalui teknologi inseminasi di wilayah penelitian yang diikuti dengan penyediaan tenaga inseminator, kedua perlu adanya peningkatan insentif finansil kepada inseminator IB untuk meningkatkan kinerja mereka.

2. Perlu dilakukan penelitian lanjutan untuk mengetahui dampak teknologi inseminasi terhadap biaya dan pendapatan peternak diluar usahatani serta konsumsi dan tabungan rumah tangga peternak

\section{DAFTAR PUSTAKA}

Badan Pusat Statistik, 2011. Sulawesi Utara Dalam Angka . BPS dan BAPPEDA Sulawesi Utara

Diwyanto, K. 2008. Pemanfaatan sumberdaya lokal dan inovasi teknologi dalam mendukung pengembangan sapi potong di Indonesia. Pengembangan Inovasi Pertanian, Vol. 1 (3):173-188
Elly,F.H., B.M. Sinaga., S.U. Kuntjoro dan N. Kusnadi. 2009. Pengaruh Biaya Transaksi Terhadap Perilaku Ekonomi Rumah Tangga Petani Peternak Sapi Potong Di Kabupaten Minahasa. Forum Pascasarjana Vol. 32 No.3 Juli 2009: $195-213$

Enisa, S, Yunilas dan Y.H Sofyan 2006. Analisis Pendapatan Peternak Sapi Potong di Kecamatan Hamparan Perak Kabupaten Deli Serdang. Jurnal Agribisnis Peternakan Vol 2. No.1, April 2006 :36-42

Fakoya, E O. 2007. Utilization of Crop

- Livestock Production Systems for Sustainable Agriculture in Oyo State, Nigeria J. Soc. Sci., 15(1): $31-$ 33

Greene, W.H. 2003. Econometric Analysis. Fourth Edition. Prentice Hall

Hadi, P.U. dan N. Ilham. 2002. Problem dan Prospek Pengembangan Usaha Pembibitan Sapi Potong di Indonesia. Jurnal Penelitian dan Pengembangan Pertanian 21(4): 148-157.

Hartono,B. 2006. Ekonomi Rumah Tangga Peternak Sapi Perah : Studi Kasus di Desa Pandesari Kecamatan Pujon Kabupaten Malang. Animal Production Vol 8 No.3, September 2006, 226-232 
Hoddi, A.H., M.B. Rombe dan Fahrul. 2011 Analisis Pendapatan Peternak Sapi Potong Di Kecamatan Tanete Rilau Kabupaten Barru. Jurnal AGRIBISNIS Vol X (3) September 2011: 98-109

Kariyasa, K. 2005. Sistem integrasi tanaman ternak dalam perspektif reorientasi kebijakan subsidi pupuk dan peningkatan pendapatan petani. Jurnal Analisis Kebijakan Pertanian 3(1): 68-80.

Koutsoiyannis 1977. Theory of Econometrics : An Introductory Exposition of Econometrics Methods. Second Edition. The Macmillan Press Ltd London

Priyanti. A. 2009. Dampak Program Sistim Integrasi Tanaman Ternak Terhadap Alokasi Waktu Kerja , Pendapatan dan Pengeluaran Rumah Tangga Petani. Forum Pascasarjana Vol. 32 No.3 Juli 2009: 195-213

Rochaeni, S dan E.M. Lokollo 2005. Faktor-faktor Yang Mempengaruhi Keputusan Ekonomi Rumah Tangga di Kelurahan Situgede Kota Bogor. Jurnal Agro Ekonomi Vol 23 (2). :133-157

Soedjana, T..D. 2007. Sistim Usahatani Terintegrasi Tanaman-Ternak Sebagai Respons Terhadap Faktor
Resiko. Jurnal Litbang Pertanian 26(2) 2007:82-87

Sudarsono, 1995, Pengantar Ekonomi Mikro. Ed Revisi. LP3ES. Jakarta

Sulin, I., Saladin, Suardi, Z. Udin, dan K. Mudikdjo. 2006. Kontribusi pendapatan usaha peternakan rakyat sapi lokal pesisir dan sapi silang pesisir 1B. Jurnal Ilmu-llmu Peternakan IX(2): 138-148.

Winarso, B., R. Sajuti, dan C. Muslim. 2005. Tinjauan ekonomi ternak sapi potong di Jawa Timur. Forum Penelitian Agro-Ekonomi 28(2): 61-71. 